\title{
The Impact of the Employment Contracts Act on Women at Work
}

\author{
Suzanne Hammond and Raymond Harbridge*
}

\section{Introduction}

The celebration in New Zealand this year of the centennial of universal suffrage has an ironic twist. One hundred years ago New Zealand was internationally heralded as a "social laboratory". The basis of this social laboratory was that equity would be achieved through legislative requirement. Suffrage was but one aspect of that experiment which included a raft of legislation controlling employment standards in shops, offices and factories. These innovative social policy developments had drawn the attention of social commentators Albert Metin and Sidney and Beatrice Webb. Metin commented that "colonial labour movements had achieved much more than their continental counterparts" and the Webbs' claimed that the "purpose of all Seddon's measures is economic and social equality" (Castles, 1985: 12).

A key policy initiative in seeking a fairer social system was the introduction of a system of conciliation and arbitration which set basic minimum wages and conditions for workers. In principle, the Industrial Conciliation and Arbitration Act recognised that the operation of the "free market" had failed to provide a fair and reasonable wage for many workers. Furthermore, by encouraging worker organisation, the Act recognised that the employment relationship is essentially asymmetrical by nature. The introduction of a legal regime based on the principles of collective labour law was an acknowledgement that the earlier regime based upon principles of "freedom of contract" was an inappropriate mechanism for the governance of the employment relationship. This had been well illustrated in the findings of the 1890 Sweating Commission. "Freedom of contract", it had found, resulted in the exploitation of many workers, particularly women.

One hundred years later New Zealand is again being seen as a social laboratory, as workers are confronted with a legal regime that has favoured the principles of individualism over collectivism in governing the employment relationship. The Employment Contracts Act purports to offer them "freedom" and "choice" in a labour system based on contractarian notions rather than collective labour law. It is ironic that a century of suffrage is being celebrated at the very time when women's rights in employment are under particular threat.

\footnotetext{
University of New South Wales, Sydney, Australia and Victoria University of Wellington, New Zealand, respectively. The authors are very grateful to Nick Howard, James Moulder and Charlie Welch for research support; to Judith Byrne, Leslie Haines, Sarah Oxenbridge, Rose Ryan, and Trish Sarr who generously gave of their time in reviewing the data; to the Ministry of Women's Affairs who gave a research grant to enable the incorporation of a gender factor in our dataset; to the Faculty of Commerce and Administration and the Internal Grants Committee of Victoria University of Wellington for research grants; and to the many hundreds of employers and union officials who supplied us with the contracts on which this work has been based.
} 
The notion of contractual relations developed alongside the emergence of capitalism in the 18th Century. The ideological framework of capitalism, based upon the notion of the free acting individual, was inimical to the status based structure of feudal society. In moving from feudalism, employment relations were derived from the household relationships found in the then master and servant legislation. Paternalism and status were the order of the day. In the liberal capitalist society of the nineteenth century, prominent social theorist Spencer saw contract as the way to liberate individuals from traditional shackles, allowing them freedom to shape their own destiny and giving them the freedom to choose their own obligations through the bargaining process of the market (Spencer quoted in Fox, 1974: 210). This conception of law is imbued with the notion of liberalism. Liberal philosophy presents the legal system as a neutral, independent and apolitical mechanism for resolving social tension (Stubbs, 1986: 65). Contract is a set of abstract relations, the agreement of two autonomous wills creating a binding engagement, which may be altered only if a new agreement is made or if it is proved that the will of either parties was not autonomous at the time of the agreement (Goldman quoted in Sorrell, 1979: 25). Capitalist society, based as it is on the notion of the market and exchange, required a framework that created the legal obligations arising from agreement to perform promises.

In 1991 the New Zealand Government introduced the Employment Contracts Act. We conceptualise this Act within the ideological framework of legal liberalism. The Act is based on the notion that the employment relationship is best governed by principles of "freedom of contract" where individuals are free to make whatever bargains they please with whomever they please (Epstein, 1983: 1349). This view was proclaimed in the often quoted statement by one of the 20th century's prominent legal theorists:

$\mathrm{A}, \mathrm{B}$ or $\mathrm{C}$ each, as a rule, judge more correctly than can anyone else of his own interest, and the conclusion naturally follows that, in the absence of force or fraud, A or B ought to be allowed to bind themselves to one another by any agreement which they choose to make ie. which in the view of each of them promotes his own self interest or in other words, is conducive to his own happiness. (Dicey, 1952: 150)

Epstein argues that individual liberty and the facilitation of social and economic relations is best achieved through the mechanism of contract, property and tort law. Concomitant with these views is the notion that the law provides a neutral mechanism through which contracts are to be enforced. According to these ideals, the law is separate from politics, intrinsically neutral and value free (Stubbs, 1986). This ideological veneer of the neutrality of law is essential for the maintenance of the legitimacy of the capitalist state and it is within these ideological presumptions that we can draw connections between legal liberalism, the "free market" and the employment contract. In a contract based labour regime, the role of the law is to provide a "neutral" mechanism to support individuals making free employment contracts.

This conception of the relationship between law and society is largely artificial and has been perpetuated by those whose class structure it reinforces - middle class (usually male) lawyers and politicians. It is argued that:

the structural characteristics of the western legal system - its formality, its generality, its autonomy and its professionalism - function to mediate social tension in the political interests of capital, an interest that we have seen is necessarily predicated upon the political, sexual and economic subordination of women (Stubbs, 1986: 65).
By implying principles of impartiality and failing to recognise actual inequalities, the legal system is perpetuating and preserving structural inequalities. Legislation such as the Employment Contracts Act, founded as it is upon the ideals of legal and economic liberalism assumes that we live in a classless, genderless and ethnically homogenous society. We don't

It is within these basic assumptions of freedom and equality that the appropriateness of the individual contract of employment comes under scrutiny. While Western liberal democratic societies officially support the tenets of free enterprise and the ideology of merit, it is inequality which constitutes the very essence of this value system (Thornton, 1990). It is this very contradiction which calls into question the appropriateness of the liberal notion of contract as a method of governing the employment relation.

Kahn-Freund argued that a view of society as an agglomeration of individuals who are coordinated as equal is a fatal error engendered by a myopic neglect or deliberate refusal to face that the main characteristic of society is the unequal distribution of power (1977: 3). KahnFreund identifies the fundamental contradiction of legal liberalism as applied to the employment contract. The employment relationship is not equal in that one party has the duty to obey, and one party has the right to direct. One party is subordinate to the other. A relationship which is based on subordination and domination restricts the "freedom" of the subordinate party. Subordination is exacerbated for women as the employment relation also reinforces and perpetuates patriarchal domination. Women are more likely to be "subordinates" in the employment contract, men are more likely to be super-ordinates.

Furthermore, a woman's ability to effectively bargain a satisfactory contract is exacerbated by the patriarchal nature of the bargaining process. Bargaining has historically been the domain of males, the language is masculinist, the processes are adversarial and its concepts have been based on gendered notions of workers being full-time, male breadwinners. These processes have, for the most part, treated women as outsiders and are unfamiliar to many women workers. To argue that women will achieve freedom and equal bargaining status in a predominantly masculinist bargaining process is to disregard the structural impediments that women face in pursuing equality in the labour market. Freedom is also contingent upon one's freedom to choose whether or not to enter a relationship. If one's choices are constrained, then freedom is limited. Working women's choices are restricted by a gender segmented labour market. Free market ideals of freedom, mobility and flexibility are fictional for those women workers who are channelled into low paid, dead end occupations.

This paper examines the hypothesis that a legal regime based upon principles of "freedom of contract" has no advantage for women workers and that, in fact, women are less well off under such a system. Empirical data on the effects of the Employment Contracts Act on collective bargaining coverage and the content of collective employment contracts are presented and analysed to determine whether women workers have fared as well as their male counterparts under the employment contracts system. 


\section{Data gathering}

The Employment Contracts Act is directed at decollectivising employee relations, encouraging enterprise bargaining over multi-employer bargaining, and promoting individual rights as equal to those of any collective. A direct corollary of these policies is reflected in the decision to keep no public record of collective bargains. Confidentiality of settlement outcomes has become an important aspect of negotiations. While Government policy has determined that there will be no public record of collective bargains, it has decided that, for "analytical and research" purposes, employers who enter into collective employment contracts that cover 20 or more staff should forward copies of those contracts to the Secretary of Labour. No such obligation rests with unions or other employee organisations who enter into contracts. The absence of a comprehensive public record of collective bargaining has made it very difficult to ascertain the effects of the legislation.

Given this new Government policy, primary data gathering has become a necessary first step for any comprehensive review of the effects of the employment contracts legislation. For the research reported here, primary data gathering has consisted of attempting to collect as many collective employment contracts as is possible, irrespective of the size of each contract. For a review of the method adopted see Harbridge (1993). It should be stressed however that the data reported cannot claim to be a complete dataset - clearly there are collective employment contracts that have been settled that have not been made available for inclusion as part of this database.

As part of our analysis, a gender component has been determined for each contract. The percentage of women workers covered by each contract has been estimated. This has been achieved by a number of methods. First, many of the contracts include the names of the individual workers party to them. A review of these names has enabled an accurate estimate of the gender component. Second, where there has been no list of workers party to the contract specified, the employers and unions who have negotiated the contract have been asked to estimate the percentage of women workers covered by the contract. This has proved difficult in many cases. Many unions, however, now have accurate data regarding the gender of their members and in many cases have this information broken down by workplace. Likewise, many employers had comparatively little difficulty in assessing the percentage sought. There were 25 contracts for which our analysis of each variable was complete except for the gender component - these 25 contracts have been excluded from these results.

In analysing the data, differences in outcomes based on gender have been sought. Two approaches to analysing the data have been taken. Some data have been weighted according to the number of women and men receiving the benefit or contract condition. In the case of wage movements, both the raw and the annualised wage movement in each contract has been weighted by the number of women and men covered by the contract. This has enabled the presentation of a series of data that report the weighted mean wage increases for women and the weighted mean wage increases for men. The other approach used to determine the relative effects of the employment contracts system on women and men workers has been to re-group the data into three sets - contracts covering "mainly women", contracts covering "mainly men" and contracts that are "mixed" and that cover similar numbers of women and men. Comparison of differences in data between these three groups was then undertaken.
Two methodological problems require discussion - first, what level of coverage makes a contract a "mainly women" contract; and second, how to determine the importance of any differences observed between "mainly women" and "mainly men" contracts. First, the difficulty in determining what level of coverage makes a contract "mainly women". Various cut-off points are available. Gwartney-Gibbs (1988), when reviewing sex segregation in the paid workforce, tackled the problem by defining the "female type" as those with less then one third males, the "male type" as those with less than one third females and those inbetween as "mixed". The difficulty with this option is that over time the participation rates of women in the workforce change and a time series approach may be invalidated. A way to circumvent this difficulty is to incorporate the female workforce participation rate into the groupings. Using this approach, the "mainly women" contracts could be those where the percentage of women covered by the contract is greater than one and a half times the proportion of women in the (full time) workforce - presently 43 percent. Applying this, "mainly women" contracts then are those where 65 percent of the workers covered are women; "mainly men" contracts are those where 35 percent of the workers covered are women; and "mixed" are those contracts inbetween.

The regular method of determining whether observed differences are of any statistical significance is to apply a conventional statistical test such as chisquare. Because of the methods of acquiring the contracts in the first place, the population of contracts held is not a random sample of all contracts that have been entered into. It is a very large sample, but not a random one. Conventional statistical tests for significant differences are based on the assumption that the sample is a random one and accordingly it is incorrect to use chisquare to confirm statistical significance. While it is incorrect to use chisquare, it may not be inappropriate, as significance testing is really about confirming the importance of differences that are otherwise obvious. With that caveat, chisquare scores will be reported herein as a further guide to the important differences based on the gender component.

\section{Results}

The data in this paper report 1,101 collective employment contracts covering 187,000 workers and some 8,300 employers. This sample represents 31 percent of the unionised workforce as at 15 May 1991, 26 percent of workers covered by collective settlements in the 1989/90 wage round, and 17 percent of the full time workforce. Of the 187,000 workers covered by the contracts examined, 89,000 (47.5 percent) were women. However, the percentage of women covered by each contract is by no means as evenly distributed. The distribution of contracts and their coverage by gender is reported in Table 1 . Contracts where men make up 80 percent or more of the contract's total coverage cover, on average, just 100 workers, whereas contracts where women predominate and make up 80 percent or more of total coverage cover nearly three times as many workers. Simply, women are covered by the larger contracts. 
Table 1: The distribution of collective employment contracts by gender.

\begin{tabular}{lccc} 
Percentage of women & Contracts & $\begin{array}{l}\text { Total } \\
\text { Coverage }\end{array}$ & $\begin{array}{l}\text { Mean coverage } \\
\text { per contract }\end{array}$ \\
\hline $00-20$ percent & 544 & 54,573 & 100 \\
$21-40$ percent & 157 & 21,186 & 135 \\
$41-60$ percent & 153 & 38,983 & 255 \\
$61-80$ percent & 105 & 32,859 & 313 \\
$81-100$ percent & 142 & 39,672 & 279 \\
\hline Total & 1,101 & 187,273 & 170 \\
\hline
\end{tabular}

For part of the analysis herein, the data have been grouped into "mainly men", "mixed" and "mainly women" contracts. There was an evenish distribution between the three categories in terms of coverage. There were 643 contracts $(64,000$ workers) classified as "mainly men", 231 contracts $(54,000$ workers) that were "mixed", and 224 contracts $(69,000$ workers) that were "mainly women".

The distribution of contracts by industry is presented in Table 2. The data show that there are three industry sectors (wholesale, retail, hotels etc; finance; and public, community and social services) where women make up more than 60 percent of the workers covered by the contracts.

\section{Table 2: The distribution of collective employment contracts by industry and gender}

\begin{tabular}{lrrrr} 
Industry sector & Contracts & $\begin{array}{c}\text { Women } \\
\text { Covered }\end{array}$ & $\begin{array}{l}\text { Total } \\
\text { Coverage }\end{array}$ & $\begin{array}{l}\text { Percentage } \\
\text { women }\end{array}$ \\
\hline Agriculture & 18 & 242 & 803 & $30 \%$ \\
Mining & 11 & 22 & 215 & $10 \%$ \\
Manufacturing & 514 & 9,527 & 43,310 & $22 \%$ \\
Energy & 40 & 687 & 4,188 & $16 \%$ \\
Construction & 44 & 582 & 8,995 & $6 \%$ \\
Wholesale, retail, hotels etc & 94 & 14,407 & 23,661 & $61 \%$ \\
Transport, communication & 76 & 6,547 & 16,110 & $41 \%$ \\
Finance & 85 & 22,795 & 34,927 & $65 \%$ \\
Public community social service & 209 & 34,653 & 54,790 & $63 \%$ \\
Multi-industry & 10 & 5 & 274 & $2 \%$ \\
\hline Total & 1,101 & 89,467 & 187,273 & $48 \%$ \\
\hline
\end{tabular}

The distribution of gender according to whether the contract was in the public or private sector is presented in Table 3. For this paper, the term "public sector" has been taken to include the core public service, health, education, rail, electricity and local government but not post or telecommunications. The data show the domination of the private sector contracts in the database with just 71 contracts covering 39,000 workers being in the public sector. The main explanation for this private sector dominance is that comparatively few public sector contracts had been settled, ratified and forwarded for inclusion in this database by December 1992. Contracts in the public sector cover larger numbers of women than do contracts in the private sector.

Table 3: The distribution of collective employment contracts by public or private sector and gender

\begin{tabular}{|c|c|c|c|c|}
\hline Sector & Contracts & $\begin{array}{l}\text { Women } \\
\text { Covered }\end{array}$ & $\begin{array}{l}\text { Total } \\
\text { Coverage }\end{array}$ & $\begin{array}{l}\text { Percentage } \\
\text { women }\end{array}$ \\
\hline Private Sector & 1,030 & 62,342 & 148,521 & $42 \%$ \\
\hline Public sector & 71 & 27,125 & 38,752 & $70 \%$ \\
\hline Both sectors & 1,101 & 89,467 & 187,273 & $48 \%$ \\
\hline
\end{tabular}

Regarding the process used to reach settlement of a collective employment contract, most workers in this sample were represented by a traditional trade union. Around 12 percent of the total sample were not represented by anyone in contract negotiations. Of those not represented by anyone in negotiations, 5,800 were women (six percent) and 16,336 were men (17 percent). Men were much more likely not to be represented by a union or other bargaining agent in contract negotiations than were women.

\section{Contract content: wages}

Wage movements occurring in contracts have been calculated. Not all contracts contain wage rates - 202 contracts covering 17,000 workers contain no wage rates, just other non-wage conditions of employment. "Mainly men" contracts were no more likely than were "mainly women" or "mixed" contracts to not contain wage rates. Eighty-two percent of "mainly men" contracts contain wages while 84 percent of "mainly women" contracts contain wages.

Specific payments based on productivity were identified in just 46 contracts (five percent of all contracts). Such payments were far more likely to appear in "mainly men" contracts (56 percent) than in "mixed" contracts (26 percent) or in "mainly women" contracts (17 percent). The differences reported were not statistically significant however.

The minimum adult wage is set by statute at $\$ 245$ per week. The minimum adult weekly wage rate in each contract was recorded and then weighted according to the number of workers covered by each contract. The weighted mean minimum adult weekly wage was $\$ 356.67$ per week. The minimum wage rate was also weighted according to the number of 
men and women workers covered by each contract. The weighted mean minimum adult weekly wage for women was $\$ 352.65$ per week while the equivalent figure for men was $\$ 360.40$ - a difference of just under $\$ 8.00$ per week.

Where wage rates were present, the percentage wage movement has been calculated by comparing the printed rate for a position in the new employment contract with the printed rate for the same position in the predecessor contract or Arbitration Commission registered settlement. No discount for inflation is incorporated in the data so the movements reported are nominal changes. Clearly, the measure reported is not in all cases the actual level of wage movement that has occurred in the new contract. In some cases, the increment reported reflects the incorporation of "above award" payments into the new printed wage rates. In other cases, the increment reported may be offset against another condition that has been removed from the contract. Also, there is some evidence that there is a consolidation of pay rates so that the one rate of pay includes all special allowances and payments. Where this consolidation or incorporation of above-award payments has demonstrably taken place, that contract has been excluded from the wage increment calculation so as to ensure that the movements reported are genuine wage movements. Other contracts have also been excluded from the dataset, including contracts where there was a gap of 18 months or more between the coming into effect of the new contract and its predecessor; contracts which were new and where no predecessor settlement could be identified; and a small number of settlements where it was not possible to determine the annualised percentage increments because the contracts contained no term or expiry clauses. There were 557 contracts covering a total of 129,800 workers where the percentage wage change over a predecessor settlement has been calculated.

Two measures of wage movement are presented in Table 4 - the raw wage movement and an annualised wage movement. The annualised movement expresses the value of the raw wage movement over a 12 month period and takes into account factors such as whether the increase is backdated to the expiry of the predecessor settlement, whether the increase is stepped etc. A full explanation of the methodology used to calculate the annualised increment is available in Ansell, Brosnan and Harbridge (1990).

Table 4: Mean weighted percentage wage movements by gender.

Gender

Raw wage movement

Annualised wage movement

\begin{tabular}{lll}
\hline Mean Male & $0.69 \%$ & $0.37 \%$ \\
Mean Female & $0.28 \%$ & $0.14 \%$ \\
Mean Combined & $0.46 \%$ & $0.24 \%$ \\
\hline
\end{tabular}

Mean wage movements overall are very small - a raw wage movement of about half of one percent is reported. When annualised this reduces to about one quarter of one percent. Notwithstanding this very small level of wage movement, the data show that men have done very much better than women. Women received on average, wage increases approximately 0.4 percent lower than did men.
While overall wage movements are very low, a wide dispersion of settlements has been identified and some settlements have represented quite large genuine wage increases. There are 201 contracts covering 31,000 workers where the raw wage rates have increased by 4 percent of more. Workers covered by the "mainly men" contracts were significantly more likely to have had a wage increase of four percent of more than were workers in the "mixed" or "mainly women" contracts (Chisquare $=13.4 \mathrm{df}=2 \mathrm{p}<0.001$ ). Where the raw wage movement was able to be calculated, 42 percent of contracts in the "mainly men" group saw increases of four percent or more, compared with 27 percent of the "mixed" and 29 percent of the "mainly women" contracts.

\section{Contract content: hours of work}

While wage rates are obviously important, working time arrangements are an essential component in determining the total wage earned by a worker over any given period. A clock hours clause will specify the days of the week and the hours each day that the ordinary hours of work, at ordinary rates of pay, will be worked - typically $8 \mathrm{am}-6 \mathrm{pm}$ Monday to Friday. Work undertaken outside these clock hours - for example on Sunday or after 6pm during week days will attract the appropriate premium, be that an overtime or penal rate of pay. Ninety percent of contracts contain provisions for overtime and penal rates of pay. Each contract has been examined to determine whether or not it contains a "clock hours" clause. An increasing number of contracts do not contain a clock hours provision thus enabling the worker to be engaged at ordinary rates of pay at any time throughout the week. Just 72 percent of all contracts currently contain a clock hours provision. Workers covered by the "mainly women" contracts were significantly more likely than were workers covered by the "mixed" or "mainly men" contracts to be covered by a contract that did not contain a clock hours provision (Chisquare $=48.4 \mathrm{df}=2 \mathrm{p}<0.0001$ ). Clock hours provisions existed in 56 percent of the "mainly women" contracts compared with 71 percent of the "mixed" and 79 percent of the "mainly men" contracts.

A separate database of working time arrangements has been established and reported elsewhere (Harbridge and Tolich, 1993). The gender component has been incorporated into that database and, using the same approach, differences between contracts on the basis of gender have been sought. Three "clock hours" variables have been examined in detail - the days of the week which can be worked at ordinary rates of pay; the total number of hours to be worked each week; and the daily span of hours within which ordinary hours can be worked.

The "ordinary days of the week" have been classified into three types - contracts that provide for the week to be worked on four days, on the five days (Monday to Friday), or on six or more days of the week. Workers covered by the "mainly men" contracts (62 percent) and the "mixed" contracts (58 percent) were more likely to have retained the traditional Monday to Friday week than were workers covered by the "mainly women" contracts ( 49 percent). The "mainly women" contracts (45 percent) were the more likely to provide for work at ordinary rates of pay on six or more days of the week than were the "mainly men" ( 33 percent) and "mixed" contracts (34 percent). The differences were significant (Chisquare $=16.0 \mathrm{df}=2$ $\mathrm{p}<0.003$ ) 
The total hours per week to be worked at ordinary rates of pay were classified into three groups - contracts that provided for less than a 40 hour week; contracts that provided for the 40 hour week; and contracts that provided for greater than the 40 hour week. The "mainly men" contracts provided for a longer week than the "mixed" and "mainly women" contracts. Just five percent of the "mainly men" contracts provided for a week under 40 hours whereas 21 percent of the "mixed" contracts and 25 percent of the "mainly women" contracts provided for a week shorter than 40 hours. Eighty-eight percent of the "mainly men" contracts provided for a 40 hour week compared with 73 percent of the "mixed" and 71 percent of the "mainly women" contracts. The differences were significant (Chisquare $=77.5 \mathrm{df}=4 \mathrm{p}<$ 0.0001 ).

The daily span of hours within which ordinary hours are to be worked were grouped into two types - contracts providing for a daily span of 10 hours or less and contracts providing for a span of 11 hours or more. The "mainly women" ( 52 percent) and "mixed" (52 percent) contracts were significantly more likely to provide for a span of 10 or less hours than were the "mainly men" contracts (41 percent) (Chisquare $=8.5 \mathrm{df}=2 \mathrm{p}<0.015$ ).

A good number of contracts (46 percent) provide for the operation of shift work. Shift work enables the operation of plant or the employer's operation outside clock hours without the necessity to pay penal and overtime rates of pay. Generally shift allowances are paid as compensation for working shifts. Contracts covering "mainly men" were more likely (50 percent) than were those covering "mixed" (44 percent) and "mainly women" (40 percent) to contain provisions enabling shift work. The differences were significant (Chisquare $=7.3$ $\mathrm{df}=2 \mathrm{p}<0.025$.

\section{Contract content: leave}

Annual, public holiday and special leave are entitlements available through statute. A minimum of three weeks annual leave is provided; 11 statutory holidays are recognised; and a minimum five days "special" leave for use as sick, domestic, or bereavement leave is specified. Employment contracts provide for these and other types of leave.

Annual leave based on service is a common provision in contracts. After a qualifying period of service, generally five, six or seven years service, a fourth week of annual leave is commonly granted. Some 103 contracts covering 13,000 workers provide for either no leave or unspecified, discretionary leave - these contracts have been excluded from the sample here. Contracts have been grouped according to whether the fourth week of leave is available before or after six years of service. Twenty-four percent of all contracts provide for the fourth week of leave before six years of service have been completed. Workers covered by the "mainly women" contracts (33 percent) are significantly more likely than those covered by either "mixed" (18 percent) or "mainly men" contracts ( 23 percent) to receive the fourth week of leave before completing six years of service (Chisquare $=12.7 \mathrm{df}=2 \mathrm{p}<0.002$ ).

Most contracts provide for sick leave in accordance with, or in excess of, the minimum statutory provision. Some 36 contracts covering 10,000 workers contained either no sick leave provision or provided for sick leave at the employer's discretion. These contracts have been excluded from this sample. Contracts have been grouped according to whether workers received more or less than seven days sick leave. Altogether 60 percent of contracts provided for seven or fewer days sick leave. Workers covered by the "mainly women" (56 percent) and "mixed" (55 percent) contracts were significantly more likely to be entitled to 8 or more days sick leave per annum than were workers covered by the "mainly men" contracts (30 percent) (Chisquare $=71.9 \mathrm{df}=2 \mathrm{p}<0.0001$ ).

Long service leave is provided for in 80 percent of contracts but workers covered by all types of contracts are equally entitled to such benefits.

\section{Gender differences in the private sector}

It was considered possible that the results reported above may show different findings if the women-dominated public sector contracts were excluded from the sample. Accordingly a separate analysis of the 1030 private sector contracts covering 149,000 workers was undertaken.

The overall patterns reported above for the combined public and private sector dataset were replicated in the private sector data. Contracts classified as "mainly women" contracts wer no more likely to contain wage rates than the "mainly men" contracts; productivity payments were more likely to appear in the "mainly men" rather than the "mainly women" contracts "mainly women" contracts were significantly more likely not to contain a clock hours provision than were "mixed" or "mainly men" contracts (Chisquare $=36.2 \mathrm{df}=2 \mathrm{p}>0.0001$ ) and sick leave of 8 or more days per annum was significantly more likely to be available in "mainly women" and "mixed" contracts than "mainly men" contracts (Chisquare $=70.7 \mathrm{df}=$ $2 \mathrm{p}<0.0001)$.

There were two areas where private sector contracts differed from those in the total dataset annual leave and shift work clauses. Workers covered by the "mainly women" contracts (29 percent) remained more likely to qualify for a fourth week of annual leave before completing six years service than workers covered by "mixed" (16 percent) or "mainly men" contracts (25 percent), but these observed differences were no longer statistically significant. Unlike the contracts in the combined dataset, the "mainly men" contracts were no more likely to contain shift work clauses. Shift work clauses were contained in 51 percent of "mainly men" contracts, 49 percent of "mainly women" contracts and 44 percent of "mixed" contracts. These differences were not significant.

\section{Interpretation of the results}

Clearly we have presented a lot of data - its synthesis has not been simple. It seems to us, however, that there are three areas where we can make some important interpretative comments regarding our findings. First, regarding the level of collective bargaining coverage among women workers. Second, that women appear to have achieved demonstrably better conditions for leave than have men. Third, that women have fared demonstrably worse than have men in respect to wage increments and to conditions of work that boost wage payments. 


\section{Collective bargaining coverage}

The data presented indicate that women make up 47.5 percent of all workers covered by collective bargains in this dataset. There is no way of directly comparing this with the collective bargaining system that operated under the Labour Relations Act. While reliable data on overall collective bargaining coverage has been estimated and reported in the predecessor project to this (Harbridge, 1991), no gender factor was incorporated into earlier datasets. Further, union membership data as collected annually by the Registrar of Unions did not require returns to be disaggregated by gender. In the absence of a requirement for unions to report membership to a Registrar of Unions, the Industrial Relations Centre of Victoria University of Wellington has taken over the collection of such statistics, expanding the annual survey of unions so as to specifically include data on gender.

In the year ended 31 December 1991, women made up exactly 50 percent of all union members (Harbridge and Hince, 1993). It is not an unreasonable assumption that women's participation rate in unions is, for all intents and purposes, broadly similar (if not identical) to collective bargaining coverage rates. That being the case, the data presented in this paper indicates that, in a shrinking collective bargaining system, women have retained their overall level of coverage. Further, this dataset, as outlined above, contains comparatively few public sector workers - and women make up some 70 percent of the public sector workforce. Workers in health, education and the core public sector are likely to settle collective contracts (if they haven't already done so) shortly and when this occurs, women are likely to make up at least 60 percent of the collectivised workforce. For some this will be a surprising finding the expectation was that women would be more likely than men to fall out of the collective bargaining system.

A variety of explanations for the finding that women are more likely to be collectivised than are men can be offered. Some will contend that women have "stuck together" to protect their existing working conditions. An alternative explanation is that, as has been demonstrated by Harbridge (1993) and Andrews and Rasmussen (1993), larger employers are more likely to enter into collective employment contracts than are small employers. While overall labour market data in New Zealand on employment by gender is sketchy, women workers are concentrated in both very large and very small workplaces. Accordingly it is unsurprising that, compared to men, women workers have remained so collectivised.

Notwithstanding the fact that women have remained as collectivised as men, a very large number of women have moved out of the collective bargaining system and onto individua contracts. Elsewhere the collective bargaining system is estimated to have shrunk by about 45 percent overall (Harbridge, 1993). Based on that assumption, we could (albeit crudely) estimate that some 165,000 women workers who used to be covered by collective agreements are now on individual contracts. There is no way of knowing whether the terms of these individual contracts are better or worse than the collectives they superseded, but the smart money, based on anecdotal evidence, would have to support the claim that women are more often worse off than they are better.

\section{Women and leave}

The data indicate that women on collective employment contracts have better sick and annua leave entitlements (both of which are based on length of service) than their male counterparts. Women were more likely to work under contracts that contained entitlements to eight or more Woms sick leave per year than were men, and women were more likely to qualify for a fourth week of annual leave before completing six years service than were men. Further, while not strictly a leave condition, weekly full time hours have favoured women over men. Women are more likely than men to be covered by contracts requiring them to work less than a 40 hour week for a "weeks pay". A reduction in leave entitlements has yet to become the focus of an employer driven offensive in the way that both wages and penal and overtime rates have. So, to some extent, the data presented probably represent a snapshot of what existed under the Labour Relations Act negotiated settlements, and what has since been "rolled over".

It could well be that women were doing better than men on leave entitlements before the employment contracts legislation was enacted. Why were women doing better than men on leave? One (albeit cynical) explanation for this somewhat surprising finding could be that employers agreed to better service based leave conditions knowing that women have high employment turnover and were unlikely to qualify for these enhanced leave benefits. An alternative (and more practical) explanation would be that women unionists, aware of the needs of women workers for improved leave, have pushed leave claims in negotiations, particularly in the mid to late $1980 \mathrm{~s}$ - possibly sacrificing wage increases as a trade off for better leave. Women unionists spoken to privately (and very much off the record) indicate that this was indeed the case but we are unlikely to be able to document such a strategy, if it existed. For whatever reason, however, the fact remains that the data indicate that women receive better leave entitlements than do men.

\section{Women and monetary benefits}

At the outset, let us state the obvious. Workers covered by collective employment contracts have on average, received minuscule "raw" and "annualised" wage increases since the implementation of the Employment Contracts Act. At best, the raw wage movement is half of one percent which when annualised into a standard 12 month period, reduces to one quarter of one percent. The data reported, however, indicated that men have on average done very much better than women workers, with men achieving wage increases nearly half of one percent larger than their women counterparts. In addition, contracts where wages have increased by more than four percent cover "mainly men", so the recipients of the larger wage increases that have resulted from the collapse of traditional relativities have been men no women. Men have done demonstrably better than women in terms of wage settlements.

As we have indicated earlier, wage settlements and rates in themselves are but one aspect of determining the total weekly wage packet. The application of penal and overtime rates to basic rates are a major factor in determining the final wage result for many workers. Overtime rates apply for work performed outside formal "clock hours" and penal rates apply for work performed at what has traditionally been seen as inconvenient hours (night, Saturday 
and Sunday work). The data demonstrate that women were more likely to be covered by contracts that didn't contain a "clock hours" provision, and so were less likely to attract overtime or penal rates for inconvenient working hours. Further the data show that women were more likely than were men to be covered by a contract that required them to work for ordinary rates of pay on any day of the week, losing the opportunity to boost basic pay rates with penal rates for Saturday or Sunday work. The very strong evidence presented is that women workers have experienced not only lower wage movements than have men, but that their ability to attract overtime and penal rates has been severely restricted.

\section{Conclusion}

One time NZ Business Roundtable employee, Penelope Brook (1990) quotes E.F. Paul:

\begin{abstract}
Rather than condemning the market, feminists ought to be glorying in it, for it has proved remarkably adaptable to women's evolving desire to work full-time, to work throughout their lives, and to work in new challenging jobs ... Why emphasise women's disadvantages alleged victimization, their helplessness ... Indeed it is the opponents of comparable worth, ... who have a positive attitude towards women's abilities, who see women as capable of determining what is in their own best interests and working for these goals in the market place alongside men, without any special privileges (p.149).
\end{abstract}

Paul and Brook argue that the common law contract of employment is the appropriate mechanism through which workers can achieve freedom and equality in the employment relationship.

This study indicates that the Employment Contracts Act does not offer any advantage to women workers and that in fact, it has clearly disadvantaged women workers. We sugges that those who are interested in issues of equity should be concerned with the trends that are emerging. This study indicates that men have done much better than women in their wage packets. Men are more likely to receive larger wage increases than women and the malefemale wage differential is likely to widen owing to the gender pattern that is emerging in changes to clock hours. Men are more likely to attract penal and overtime rates whereas many women workers have lost these allowances. While changes in clock hours have allowed greater flexibility in the variation of working time, for women this has come at the cost of allowances. One is cautioned to ask "whose flexibility"? Pollert (1991) argues that flexibility has become a synonym for unfettered managerial perogative. Flexibility will only benefit women workers if they have the choice to make work arrangements that suit them, and flexible working time offers no advantage if it is solely determined by managers. As Sayers (1993) warns, "flexibility" may cause greater polarisation and exacerbate the division between the core and periphery workforces.

Men are also more likely to receive productivity based payments. This indicates a failure to resolve sexist notions of skill and productivity assessment. In a system that purports to encourage individual incentive and performance pay, women's under-representation in collective contracts offering these arrangements will further worsen the position of women in employment.

The most optimistic outcome of this study is that women in collective contracts have done better than men in respect of leave entitlements. However we caution that the contracts we have examined are likely to be the "better" contracts as an employer that has significantly cut pay and conditions may have felt unwilling to have such a contract examined - even with the confidentiality undertaking offered. Further, owing to the difficulties of data collection of individual contracts emanating from the Act, it is very difficult to get a clear picture of what is happening to workers covered by individual contracts.

This study indicates that the Employment Contracts Act does not deliver "equality" and "freedom" to women workers. To suppose that it is in women's own best interest to embrace free market ideals and its concomitant legal regime is to ignore structural impediments to women's equality which are inherent in our society. One hundred years ago it was acknowledged that the employment relationship was inherently unequal and that positive legislation was required to alleviate this imbalance. A century later the ideals of freedom of contract and equality in the employment relationship are just as fallacious.

\section{References}

Andrews, G. and Rasmussen, E. (1993), Quarterly Employment Survey February 1992 survey of employment contract coverage, Paper presented to the 7th Association of Industrial Relations Academics of Australia and New Zealand conference, University of Auckland, 2023 January.

Ansell, J., Brosnan P., and Harbridge R. (1990), When is 3 plus 1 equal to 3.1 - methods of examining wage settlements to determine their annual rate of adjustment, New Zealand Journal of Industrial Relations, 15(1): 49-60.

Brook, P. (1990), Freedom at Work, Auckland, Oxford University Press.

Castles, F. (1985), The Working Class and Welfare, Wellington, Allen and Unwin.

Dicey, A.V. (1952), Law and Public Opinion in England during the Nineteenth Century, London, MacMillan and Co Ltd.

Epstein, R.A. (1983), A Common Law for Labor Relations: A Critique of the New Deal Labor Legislation, The Yale Law Journal, 92(8): 1357-1408.

Fox, A. (1974), Beyond Contract: Work Power and Trust Relations, London, Faber and Faber.

Gwartney-Gibbs, P.A. (1988), Sex segregation in the paid workforce: the New Zealand case, Australia New Zealand Journal of Sociology, 24(2): 264-278.

Harbridge, R. and Hince, K. (1993), Organising workers: the effects of the Act on union membership and organisation, In Harbridge R. (ed), Employment Contracts: New Zealand Experiences, Wellington, Victoria University Press. 


\section{Suzanne Hammond and Raymond Harbridge}

Harbridge, R. (1991), Collective bargaining coverage in New Zealand: The impact of the Employment Contracts Bill, Australian Bulletin of Labour, 17(4): 310 - 324.

Harbridge, R. (1993), New Zealand's collective employment contracts: update November 1992, New Zealand Journal of Industrial Relations, 18(1): 113-124.

Harbridge, R. and Tolich, D. (1993), Collective employment contracts and new working time arrangements in New Zealand, Journal of Employment Studies, (Forthcoming).

Kahn-Freund, Sir Otto (1977), Labour and the Law, London, Stevens.

New Zealand Business Who's Who, (1992) Wellington, New Zealand Financial Press.

Pollert, A. (ed) (1991), Farewell to Flexibility?, Oxford, Blackwell.

Sayers, J. (1993), Women, the Employment Contracts Act and Labour Flexibility, In Harbridge R. (ed), Employment Contracts: New Zealand Experiences, Wellington, Victoria University Press.

Sorrell, G. (1979), Law in Labour Relations: An Australian Essay, Sydney, Law Book Company.

Stubbs, M. (1986), Feminism and Legal Positivism, Australian Journal of Law and Society, 3: 63-91.

Thornton, M. (1990), The Liberal Promise: Anti-Discrimination Legislation in Australia, Melbourne, Oxford University Press. 